\title{
Artigo
}

\section{Qatar's rising international influence: a case of soft power?}

Crescente influência internacional do Qatar: um caso de soft power?

DOI: 10.5752/P.1809-6182.2016v13.n1.p22

Maximilian Felsch ${ }^{1}$

Recebido em: 12 de fevereiro de 2016 Aprovado em: 24 de fevereiro de 2016

\section{Abstract}

The Arab uprisings have changed the regional order of the Arab world. As traditional leading powers like Iraq, Syria and Egypt have lost influence in the Middle East due to internal security issues and economic difficulties, a few states were able to take advantage of the recent regional turmoil. Seemingly, the mini-state Qatar has managed to benefit from the uprisings more than any other Arab state. Many IR authors explain this phenomenon with the concept of soft power. This paper tests systematically the validity of the soft power argument by examining three "soft power resources" as defined by Joseph Nye: culture, political values, and foreign policies. It is argued that the soft power concept fails in all three aspects to grasp the nature of Qatar's regional and international influence. Instead, it is suggested to consider Qatar's 'hard power' potentials which define more accurately the actual international influence of the Gulf state.

Keywords: Qatar, Foreign Policy, Soft Power, Middle East Politics, International Relations

1. Assistant Prof. and Coordinator of the Department of Political Science at Haigazian University, Beirut. orcid. org/0000-0003-1323-8475 


\section{Introduction}

Seemingly, Qatar is one of the rising powers in the Middle East and beyond, a shooting star of $21^{\text {st }}$ century world politics. Giving its tiny citizen population of only 250,000 and its limited military capabilities, Qatar appears to be a global player of a new kind. The Gulf Emirate applies intensively active diplomacy in regional conflicts, invests strategically in shares of international companies, controls the most influential Arab news channel - Al-Jazeera - and succeeded to be awarded hosting rights to the International Federation of Association Football (FIFA) World Cup 2022. According to Qatar specialist Mehran Kamrava, the country "has transformed itself into a global hub and a central pivot of globalization" (KAMRAVA, 2013, p. 1).

Qatar, which, just five decades ago, was a rural state of some sleepy fishing towns, has now entered the club of regional "great powers". As much as traditional powers like Egypt, Syria, Iran, Iraq, and Turkey have experienced, more or less, declining importance for both economic and political reasons, Qatar has taken advantage of its favourable financial and security situation to improve its regional influence. This development became more evident after the Arab uprisings in 2011.

The Qatar phenomenon has led to growing academic interest within the discipline of IR. However, notwithstanding the rising number of publications, the literature on Qatar is still not substantial. Three comprehensive text books on Qatar have been published in recent years and filled partly the gap in the respected literature: Allen Fromberz's 'Qatar: A Modern History' (2012); Matthew Gray's 'Qatar: Politics and the Challenges of Development' (2013); and Mehran Kamrava's 'Qatar: Small State, Big Politics' (2013).

Although the three monographs appeared at almost the same time, they haven't caused much duplication. Due to the authors' very distinct research interests they rather constitute complementary works. Historian Allen Fromherz examines Qatar's historical and cultural (or tribal) legacy and the impact of the British colonial rule on the emerging monarchical regime type. In contrast to Fromherz who downplays the importance of natural resources, Matthew Gray' study focuses on Qatar's energy-driven political economy and its particular rentier system. Gray's main augment is that Qatar is not a classical but a 'late rentier state'; meaning that gas revenues are invested to diversify the national economy and to strengthen international linkages with the purpose to maintain social and political stability. Although national resources are limited, Qatar, according to Gray, seems to be on a successful path of sustainable development.

The third author, Mehran Kamrava, analyses in particular Qatar's foreign policy and its active diplomacy and is therefore most relevant for our paper. $^{2}$ Kamrava (2013 p. 46-68) sees traditional or realist understandings of 'power' as outdated in contemporary international politics and proposes instead the concept of 'subtle power' which presumably explains more correctly the rise of Qatar to an influential actor in the international arena. Subtle power, Kamrava writes, is a less blunt form of influence exercised by small states in the form of diplomacy, marketing or access to commercial resources KAMRAVA (2013: p. 46-68). Most authors of recent publications on Qatar's foreign policy strategy aim at revealing the secrets of its 'success story' by applying Joseph Nye's concept of soft power (ANTWI-BOATENG 2013; HAYKEL 2013b; KAMRAVA 2011; RUBIN 2010). Deprived of significant military capabilities, soft power seems to be Qatar's real strength.

2. For a more detailed review of the three books see: Tunçer (2013) p. 229-234. 
The most systematic evaluation of Qatar's soft power can be found in Osman Antwi-Boateng's 'The Rise of Qatar as a Soft Power and the Challenges' (2013). Antwi-Boateng asserts that the focus on Qatar "demonstrates how a small country can punch above its weight by exerting soft power influence and shaping the course of history in the Middle East" (ANTWI-BOATENG 2013 p. 39). He identifies soft power in the various policies, such as Qatar's military alliance with the U.S.; its redistribution of wealth among its citizens; its higher education system; media influence; 'carrot diplomacy'; sports policy; and foreign aid. He nevertheless expresses some concerns about the viability and sustainability of Qatar's soft power strategy, but misses to develop an alternative approach and so inclines that soft power is still the most accurate analytical tool to explain Qatar's foreign policy.

More recently the soft power rationale suffered some empirical setbacks as Qatar's foreign policy strategy does often not lead to the envisaged results. This is especially apparent since the Arab uprisings when the Qatar-sponsored Muslim Brotherhood failed to come to power in Libya and Syria, or, in the case of Egypt, lost power due to a military coup. These dynamics have led to rising doubts about Qatar's real influence in the Middle East (KHATIB, 2013; DICKINSON, 2014; NEUBAUER, 2014). In addition, the rising international critique of Qatar's human rights standards in the context of the FIFA World Cup preparations has a negative impact on Qatar's image.

Against this backdrop, Windecker and Sendrowicz (2014) suggest to theorize Qatar's foreign policy as 'smart power' - another concept borrowed from Joseph Nye which refers to a country's ability to combine hard and soft power (NYE JÚNIOR, 2004, p.147).

Lina Khatib's (2013) is one of those authors who focus on the limitations and failures of Qatar's active foreign policy strategy. By arguing that due to a lack of a coherent strategy Qatar's regional diplomacy and conflict mediation are of limited impact, Khatib, at least indirectly, plays down Qatar's soft power.

In short, the Qatar debate among IR scholars has formed two opposing camps. The first one believes that Qatar's rising global importance compels IR to rethink conventional concepts of state power in international politics. This camp argues that 'soft power' or similar innovative power concepts, such as 'smart power' or 'subtle power', help to explain how a mini state is capable of influencing world politics. The other side rejects this view and either denounces the analytical value of the soft power idea altogether or denies that Qatar has any significant international influence.

This study is the first systematic and comprehensive test of Qatar's real soft power. Following strictly Joseph Nye's definitions, it will be shown that Qatar's soft power is rather a myth. Moreover, it is argued that traditional or realist conceptions of power describe and explain more adequately Qatar's foreign policy.

The paper begins with an examination of Joseph Nye's concept of soft power. This is followed by an analysis of Qatar's national strategy in terms of the three soft power resources defined by Joseph Nye, i.e. culture, values, and foreign policy. Thereupon it will be examined to what extent the realist power concept holds explanatory value in regard of Qatar's rising global influence.

\section{Conceptualizing Soft Power}

"A country may obtain the outcomes it wants in world politics because other countries want to follow it, admiring its values, emulating its example, and/or aspiring to its level of prosperity and openness." (NYE JÚNIOR, 2008, p. 94) 
The concept of "soft power" was coined by American Political Scientist Joseph Nye in his book "Bound to Lead: The Changing Nature of American Power" (1991). The original purpose of differentiating between hard and soft power was to explain the changing role of the U.S. as the sole super power in the post-Cold War era. Nye even believes that the U.S. had won the Cold War mainly because of its superiority in terms of soft power (NYE JÚNIOR, 2008 p. 94). The idea of "soft power" has inspired many other IR scholars who utilized the concept to analyze foreign policy strategies of other great powers, such as China, Russia, or the European Union (see for example: MELISSEN, 2005; BRESLIN, 2011; HUANG; DING, 2006; NIELSEN, 2013; JONES, 2009-10; TAFURO, 2014).

In various publications Nye has developed and specified his concept of soft power. The most common definition describes soft power as "the ability to get what you want through attraction rather than coercion or payment" (NYE JÚNIOR, 2004, p. x). In 2008, Nye offered a similar but slightly different explanation of soft power, defining it as "the ability to affect others to obtain the outcomes one wants through attraction rather than coercion or payment"; or in short: "soft power is attractive power” (NYE JÚNIOR, 2008, p. 94). Furthermore, in 2009 he stated "soft power is the ability to obtain preferred outcomes through attraction" (NYE JÚNIOR, 2009, p. 160).

By understanding power not in terms of resources, territory or manpower but as the ability to obtain preferred outcomes, Nye talks exclusively about state power in the international arena. Here he sees hard power at play whenever "coercion and payment" - also termed as "sticks and carrots" is applied, while with soft power "attraction" leads to a realization of a state's interest. Nye further defines three soft power resources of which states could make use of: culture, values, and foreign pol- icy (NYE JÚNIOR, 2004, p. 11; NYE JÚNIOR, 2008, p. 96).

It is noteworthy that Nye does not believe soft power alone would provide a state with the ability to achieve desired outcomes. Rather, if applied "smartly", hard and soft power would go hand in hand:

\begin{abstract}
"If a state can set the agenda for others or shape their preferences, it can save a lot on carrots and sticks. But rarely can it totally replace either. Thus the need for smart strategies that combine the tools of both hard and soft power" (NYE JÚNIOR, 2009, p.160).
\end{abstract}

Nye further indicates that soft power is not a natural or God-given asset; therefore he recommends states to actively invest in their soft power and to always be aware of their own soft power capacities. That is because soft power provides states with alternative options in foreign policy in addition to force or costly investments. The deliberate promotion of soft power is called public diplomacy, by which a state "tries to attract by drawing attention to these potential resources through broadcasting, subsidizing cultural exports, arranging exchanges, and so forth (NYE JÚNIOR, 2008, p. 95). ${ }^{3}$

John Lenczowski (2011, p. 159-192) has built on Nye's writings to develop the concept of "cultural diplomacy", a term that is often used as a synonym of soft power. His main idea in this context is that cultural diplomacy is not a matter of "low politics" (to borrow this realist terminology) but a strategic and cost effective tool of enhancing national security (LENCZOWSKI, 2011, p. 164). It should therefore be understood as an "element of national security policy” (LENCZOWSKI, 2011, p. 164). That means by investing in arts performances, exhibitions, student exchange programs, etc., states

3. The term Public Diplomacy was coined by Manuel Castells who wrote: "The aim of public diplomacy is not to convince but to communicate, not to declare but to listen" (CASTELLS, 2008, p. 91). 
can build up mutual understanding and trust with other states of which a government can benefit in terms of intelligence, military support, diplomatic support etc. Lenczowski, in accordance with Nye, laments the "lost opportunities" of particularly the U.S. foreign policy because it supposedly underutilizes cultural diplomacy (LENCZOWSKI, 2011, p. 159).

Implicitly, both Nye and Lenczowski assert that liberal values, for which supposedly the U.S. stands for, are universally attractive - and by doing that they show some ethnocentric tendencies. Therefore - and despite the increased recognition of non-military resources of influence in world politics - the concept of soft power has not remained uncontested. Todd Hall for example doubts the analytical value of soft power altogether and suggests that soft power is a useful "category of practice" but not of analysis (HALL, 2010, p. 193-197). He believes that "attraction" is not a suitable concept for developing a useful analytical tool. Furthermore, when applied by political practitioners, the concept usually serves to reinforce "pre-existing in-group biases" (HALL, 2010, p. 197). In this regard, soft power was mostly "employed to advocate and justify a certain set of values and a specifically liberal conceptualization of American identity as central to U.S. international power" (HALL, 2010, p. 196). In other words, the concept of soft power can only be applied subjectively.

It is interesting to note that although both scientists and practitioners abundantly use the concept of soft power, there have been very few attempts to actually measure the soft power of states. One exception is the magazine Monocle which in cooperation with the Institute for Government publishes since 2010 a "soft power index". This index ranks every year "30 countries who best attract favour from other nations through culture, sport, cuisine, design, diplomacy and beyond" (MCCLORY,
2010). Following Joseph Nye's ideas, Monocle assesses countries' soft power based on five categories: Business/Innovation, Culture, Government Diplomacy, and Education. Noteworthy, Monocle's list of the world's 30 strongest soft powers - which currently sees Germany as number one - has never included Qatar or any other Arab nation.

As the purpose of this paper is to test Qatar's real soft power capabilities, the following chapters will analyse Qatar's international influence in terms of a) culture; b) values; and c) foreign policy.

\section{Qatar's soft power}

The soft power of a country rests primarily on three resources: its culture (in places where it is attractive to others), its political values (when it lives up to them at home and abroad), and its foreign policies (when they are seen as legitimate and having moral authority). (NYE JÚNIOR, 2008, p. 96)

Following Joseph Nye's three soft power "resources", this chapter will test Qatar's soft power capacities in terms of culture, political values and foreign policies. We should bear in mind that all three soft power resources must be "attractive" to other societies in order to be effective assets for the pursuit of foreign policy goals.

\section{Culture}

Nye understands culture as a "set of values and practices that create meaning for a society" (NYE JÚNIOR, 2004, p. 22). This includes high culture (e.g. higher education and art that appeals to the elites) and low or popular culture that appeal to the masses (NYE JÚNIOR, 2004, p. 22). It is supposed here that Qatar in terms of "popular culture" - which includes things such as cuisine, fashion, films, music etc. - is not significantly attractive for outsiders or even known for. We therefore focus in this chapter first on Qatar's "high culture" and in 
particular its higher education system and related exchange programmes. Secondly, we will examine the backgrounds of Qatar's huge foreign population since this fact might be interpreted by some as a sign of the country's attractive culture.

Qatar has defined national strategies for a sustaining economic development of which education is a central feature. In its "Qatar National Vision for 2030" as well as in its "Qatar National Development Strategy 2011-2016", Qatar defines several educational goals, among them:

- An effective system for funding scientific research shared by the public and private sectors and conducted in cooperation with international organizations and leading international research centres, and

- A strong international role in cultural and intellectual activity and scientific research (GENERAL SECRETARIAT FOR DEVELOPMENT PLANNING, 2011, p. 122).

Furthermore, the Qatar Foundation - well known for its FC Barcelona shirt sponsorship - invests billions of dollars in a campus in Doha called "Education City" which contains branches of six American universities, one British university and one French university. Although being a non-profit organization that invests in education projects all over the Middle East, The Qatar Foundation is founded by and closely linked to the ruling family. It is widely assumed that the rational behind these enormous efforts in the field of higher education is to increase Qatar's reputation and legitimacy internationally. Thus, Qatar indeed intends to increase its soft power.

One measurable result of this strategy is the steadily increasing number of foreign students. According to UNESCO's Institute of Statistics, Qatar hosted 1,170 foreign students in 2004, 4,544 in 2008; 5,418 in 2010; and 7,154 in 2012 (UN-
ESCO 2013). These are remarkable figures for a country of its size but the crucial question for this study is whether they serve as indicators of Qatar's attractive culture. In other words, do foreign students really choose their university in accordance with the "culture" of the respected country? Or do other factors and self-interested motivations have priority (like the reputation of the university, possible business connections, the academic quality, the technical equipment, political stability, etc.)?

There are good reasons to believe that most foreign students in Qatar would also have gone to another country if the study environment was similar. As the author could not find surveys conducted among foreign students in Qatar, we can only reason that the huge financial investments in the context of a broad national education strategy are behind the growing attraction of foreign students. If so, it cannot be considered soft power according to Joseph Nye's definitions.

That said, soft power proponents might argue that even if Qatar's culture may not motivate foreign students to study there, Qatar's strategy is to attract foreign students in order to diffuse its culture, values and reputation abroad. Exchanges and contacts between citizens of different countries could indeed create familiarity and even mutual understanding which indirectly could make political cooperation between states easier and armed conflicts less likely. This is not an original idea since many IR theories do already emphasize the importance of groups and societies in international affairs; those theories include sociological liberalism (ROSENAU, 1980), Karl Deutsch's concept of "security communities" (DEUTSCH et al. 1957) and the entire field of social constructivism.

In the context of American students' exchanges, Carol Atkinson asserts in his study on the subject that "U.S.-hosted exchange programs can play an important role in the diffusion of liberal values and 
practices across the borders of authoritarian states" (ATKINSON, 2010, p. 2). Nevertheless, exchanges can also have the opposite effect; they could cause aversions among exchange participants if their value systems differ essentially (this issue will be discussed further when we tackle the international debate about human rights violations in the context of future FIFA World Cup 2022). Todd Hall gives in this regard the example of the 9/11 terrorists who have studied in Western democratic countries but did certainly not feel attracted by their democratic and liberal values (HALL, 2010, p. 199).

Nevertheless, it could still be argued that the huge number of migration workers prove Qatar's cultural attraction. In fact, only 250,000 people - corresponding to $15 \%$ of its 1.74 million inhabitants - are national citizens of which up to 15,000 belong to the ruling Al Thani family (KAMRAVA, 2013, p. 5). The largest foreign groups are the Indians (25\% of Qatar's total population), followed by Pakistanis and Bangladeshis (KANCHANA, 2012, p. 47). When we look at the labour force, out of the total 1,341,193 workers in 2012 , only 82,815 , or $6.17 \%$, are nationals according to the Ministry of Development, Planning and Statistics.

While high-skilled foreign workers - usually called "expats" - earn high salaries and are entitled to many benefits, low-skilled workers suffer from miserable working conditions (PESSOA, 2009). Amnesty international reports in a comprehensive documentation, titled "The Dark Side of Migration", exploitations and abuses of construction and domestic workers. That includes forced labour, the confiscation of migrant workers' passports, restrictions of movement and wage reductions or even no payments at all (THE DARK..., 2013). Similarly, the mainly female domestic workers suffer from exploitations and a lack of legal protection too (QATAR..., 2014). Most of these practices are legal ac- cording to Qatar's controversial Sponsorship Law ${ }^{4}$.

Given these slave-like condition, it is more than doubtful that Qatar attracts these low-skilled workers by its "culture". Nor can it be believed that foreign workers, once back home, will spread a positive image of the country. Obviously, Qatar, as many other Arab countries, merely offers poor and desperate people in developing countries job opportunities. Regarding the high-skilled "expats", Qatar's attraction lays in offering high salaries and generous benefits. In both cases, it is "carrots" (to use Joseph Nye's term again) that allow Qatar to attract the needed workforce from abroad, not its attractive culture, i.e. soft power.

Another often used argument in favour of Qatar's strength in terms of soft power is its win of hosting rights for the 2022 World Cup. For Qatar that was a sensational success by which it believed to enhance its reputation aboard by the expected global media attention and to boost the tourism sector (BRANNAGAN; GIULIANOTTI 2014, p. 154-165). By winning the bid, Qatar felt assured of being a respected and legitimate member of the international community. The World Cup 2022 bid is the greatest success of a broader national strategy of investing in sports events for political purposes. ${ }^{5}$ A systematic analysis of al Qatar's overall policy of sports is beyond the scope of this paper and we will therefore on the most significant event, the winning of the $2022 \mathrm{bid}$.

As for the real effect of the hosting rights, the

4. Qatar requires from every immigrant to have a "sponsor" who must be his or her employer. The worker has to give his passport to his sponsor and is not allowed to change his workplace or even to leave the country without the permission of his sponsor. These practices result in slavery-like conditions.

5. To mention some examples of Qatar's active sports policy: The Qatar Foundation is the main sponsor of the most popular club, FC Barcelona; Doha nationalized many African athletes to compete in Olympic games; Qatar won the hosting rights for the 2015 Handball Championship; Al-Jazeera Sport gained many exclusive Football broadcasting rights for the whole Arab region; the 2012 London Olympic Village was sold to the state controlled Qatar Sports Investment (QSI). 
paper has already laid down that it brought Qatar mainly negative international attention in the context of human rights violations and therefore has at best caused mixed impacts on its image. More important for this study is the procedure why which Qatar was granted the 2022 World Cup. FIFA's procedure of electing host countries for its tournament lacks transparency and is prone to manipulations and corruption.

This was especially true for the dual bidding for the 2018 and 2022 World Cups (OWEN, 2014). In May 2011, many international newspapers began reporting about bribery accusations against the Qatari Mohammad bin Hammam, at the time president of the Asian Football Confederation and member of FIFA's powerful executive committee. In short, Hammam was accused of having paid several executive members for their votes. In March 2014, Jack Warner, executive member from Trinidad and Tobago, was identified as one of those accepting money for his vote. FIFA has subsequently suspended both Hammam's and Warner's membership; and by doing so FIFA has implicitly acknowledged the correctness of the widespread accusations of corruption. In other words, it is quite certain that Qatar has "bought" its hosting rights. So again, it was the hard power of money and not attractive power of culture that made Qatar achieve its political objectives.

\section{Political values}

Qatar's archaic political system is based on Absolutist personal rule without any form of popular political participation or even representation. This authoritarian form of government can hardly be considered as being desired by other societies. Even in the Arab region where this form of rule is more common than elsewhere, the unprecedented protest movements, usually framed as the "Arab Spring", have proven a widespread regional desire for more freedom, participation and opportunities. Various Human Rights reports, as published for example by the U.S. State Department and transnational NGOs like Human Rights Watch or Amnesty International, regularly report of massive human rights violations. That includes the lack of freedom of expression and freedom of press, the lack of an independent judiciary, and discrimination against women (WORLD..., 2014; U.S. STATE EPARTMENT, 2011).

On the other hand, Qatar stands out in the region in terms of various factors that are assumingly seen as attractive by most: political stability; the redistribution of its enormous wealth; the absence social frictions. Those factors may be particularly attractive in times of rising political and economic crises in the region. Combined with the policy of actively supporting the Arab protests against authoritarian rule (with the notable exception of the ones in Bahrain), Qatar could indeed enhance its reputation.

Nevertheless, this chapter's preliminary quote of Joseph Nye shall be recalled here: It defines political values as a soft power resource "when it lives up to them at home and abroad". Assumed the values of the Arab uprising are based on freedom, human rights and participation, Qatar by no means lives them up at home.

In terms of political values, there is another phenomenon that has to be examined: Al Jazeera. No publication on Qatar's soft power would refrain from referring to its Al-Jazeera Satellite channel (ANTWI-BOATENG, 2013, p. 42-3; HAMMOUD, 2014, p. 2-4; HAYKEL 2013b, p. 2). Al-Jazeera was established in 1996 by Qatar's ruling family as the first pan-Arab satellite TV station and has launched an English station in 2006. Al-Jazeera - advertising with the slogan "both sides of the story" - allowed most Arabs for the first time to watch controversial debates on all political and social issues. Free discussions between politicians, 
journalists and scientists were an almost revolutionary development in the region where governments use media for ideological indoctrinations.

Not surprisingly, the mainly authoritarian Arab governments began to fear the channel as it provided opposition leaders a platform and uncovered corruption etc. It is without question that Al-Jazeera has significantly changed the relationship between governments and citizens and perhaps even served as a catalyst for the 2011 uprisings (SULTAN, 2013).

Al-Jazeera gave the Arab people a voice and took for example sides for the Palestinians in their conflict with Israel. This alone provided the channel with legitimacy and popularity due to the Arab consensus in questions related to the Israeli-Palestinian conflict. However, although it allowed even Israeli representatives to express their views (which was unthinkable in any national Arab media), Al-Jazeera has never been a neutral, unbiased and independent media outlet. It is in fact in control by the Qatari regime. Al-Jazeera is therefore not an example for a genuine "political value" that is "lived up at home"; it serves as the mouthpiece of Qatar's government and would never be critical towards Qatar's ruling family and its policies.

In accordance with the Qatar's foreign policy strategy, Al-Jazeera unreservedly took sides with the Arab uprisings. As the uprisings did not lead to the results as envisaged by the Qatari government (the military coup against Egyptian President Mursi and the ruling Muslim Brotherhood; the enduring power of Syrian President Bashar al-Assad; the continuing political turmoil in Libya), Al-Jazeera has significantly lost reputation and influence (ELDAR, 2013). In addition, it has also lost influence due to the rising importance of social media as central means of mobilization during the Arab uprisings.

Furthermore, Al-Jazeera was accused by Arab governments, including GCC allies, for organiz- ing media campaigns against their rule. Three Gulf States - Saudi Arabia, the United Arab Emirates, and Bahrain - have in March 2014 even recalled their ambassadors from Doha to protests Al-Jazeera's support for Islamist groups which are seen as threats by all other Arab Gulf States (RECALLING..., 2014).

That means, although being an instrument of Qatar's ruling family to spread its political views, Al-Jazeera is a double-edged sword for Qatar as it also led to its dangerous political isolation in the Gulf region and beyond. It is therefore a fallacy to assume a government by having power over a transnational TV channel is necessarily able to "obtain outcomes it wants in world politics", to use Nye's definition of power.

\section{Foreign policies}

Osman Antwi-Boateng (2013, p. 39) asserts that Qatar "demonstrates how a small country can punch above its weight by exerting soft power influence and shaping the course of history in the Middle East". The purpose of this chapter is to assess the accuracy of this statement. Three foreign policies are of primary importance: Qatar's proactive regional diplomacy and conflict mediation; its interventionist strategy shift since the Arab uprisings, and its alliance with the U.S.

\section{DiPLOMACY AND CONFLICT MEDIATION}

The main reason why Qatar's power is often described as a soft power is its extraordinary proactive diplomacy in terms of conflict mediation. Mediation, according to Kristian Coates Ulrichsen, "lies at the heart of Qatari foreign policy" (KAMRAVA, 2013, p. 1). Mehran Kamrava wrote in an article in 2011: "Mediation has emerged as one of the central tools for enhancing Qatari soft power and global image" (KAMRAVA, 2011, p. 556).

It seems Qatar offers its diplomatic services to almost all regional conflict parties. The purpose of which is to make itself indispensable for regional 
and global great powers. We will look at Qatar's three most relevant conflict mediations to identify the means by which Qatar affects results and assess its short-term and long-term successes. The three conflict mediations that are being examined here are the ones in Yemen, Lebanon, and the occupied Palestinian Territories. ${ }^{6}$

\section{$\underline{\text { Yemen }}$}

In 2007, Qatar mediated a peace agreement between Yemen's government and a militant Shia group, known as the Houthis, which led first to a ceasefire agreement before and eventually in February 2008 to a peace agreement which was signed in Doha. Part of the deal was Qatar's pledge to provide Yemen's government \$300-500 million to reconstruct the Saada province destructed by the war (YEMEN.., 2009; p. 4; ULRICHSEN, 2013, p. 2). The peace, however, lasted only for about one year until new fights began in March 2009, upon which Qatar withdrew its financial offers. Latest reports on the conflicts reveal that the Houthis are now involved in military confrontations with various armed groups and that the conflict zone covers way more areas (THE HOUTHIS..., 2014.) Thus, Qatar's mediation has not succeeded in Yemen.

\section{Lebanon}

In May 2008, Lebanon was on the brink of another civil war when oppositional Hezbollah and its allies attacked and temporarily occupied Sunni and Druze neighbourhoods (LEBANON..., 2008). At the time, a one-and-a-half-years lasting political crisis had resulted in a void president office and a paralyzed Parliament. Qatar's Emir, Sheikh Hamad bin Khalifa Al Thani at the time, invited the leaders of the rival political camps "March 8" and "March 14" to Doha for peace and reconciliation talks. Qatar's

6. Qatar has also been diplomatically active in Afghanistan, Ethiopia, Iraq, Israel, and Sudan; but a comprehensive analysis of Qatar's conflict mediations is beyond the scope of this paper. A more comprehensive study on Qatar's foreign policy can be found in Hansen (2013). mediation not only succeeded in ending the clashes but also solved the immediate political crisis. The Doha Agreement included inter alia the election of Michel Sleiman as President, the formation of a unity government, and a new electoral law (MAKDIDI; KIWAN; MARKTANNER, 2010).

Similar to the case in Yemen, Qatar has used significant financial incentives to assure the success of the talks as it pledged investments in Lebanon worth $\$ 300$ million (RABI 2009). Qatar's support was widely praised in Lebanon and posters with the message "Shukran Qatar" (“Thank you, Qatar!”) were placed all over the country. Although Qatar's initiative was crucial in ending the Lebanese crisis of 2008, the roots of the conflict have not been settled: Hezbollah's armament and consequently Lebanon's precarious state sovereignty on the one hand, and Lebanon's foreign policy, especially towards Syria, on the other. Thus, Lebanon suffers now (in December 2015) again from a political crisis and is without a President because the rival political camps cannot agree on a candidate.

\section{Occupied Palestinian Territories}

Qatar was also actively involved in securing a conflict settlement between the rival Palestinian factions Fatah and Hamas. Palestine is of traditional interest for Qatar. Its Al-Jazeera program as always shown the Palestinian perspective of its conflict with Israel and state-run charity organizations have been very active in humanitarian aid for Palestinians in Gaza and the West Bank (HANSEN, 2013, p. 323). Qatar also advocates internationally for Hamas to be accepted a legitimate actor representing Palestinians and has always pressured the GCC to finance the reconstruction projects in Gaza.

In February 2012, Qatar achieved the Fatah-Hamas Doha Agreement which was signed by President and PLO leader Mahmoud Abbas and the exiled Hamas leader Khaled Mishal. The agreement, however, was immature. Apart from 
being vaguely formulated and postponing final decisions, it was by many Hamas leaders in Gaza regarded as illegitimate and non-binding since they were not involved in the negotiation process (HANSEN, 2013, p. 40-1). Thus, the implementation failed.

The given examples show that Qatar's political influence in the region is limited as it is restricted to its ability and willingness to offer financial incentives to rival factions. Financial resources and the personal engagement of Qatar's political leaders positively affect mediation outcomes. However, Qatar's 'check book' diplomacy often leads to short term agreements but never to genuine and sustainable conflict settlements. Most authors who have seriously examined Qatar's mediation efforts also concluded that the success rate of Qatar's mediation efforts is rather low (HOUNSHELL, 2012; KAMRAVA，2011; KHATIB，2013; ULRICHSEN, 2013). Usually the lack of long-term solutions is explained by Qatar's lack of two important capabilities: the military capability to enforce the compliance of the mediated agreements and a professional diplomatic corps to monitor the implementation of the agreements.

\section{MUSLIM BROTHERHOOD SUPPORT AND MILITARY INTERVENTIONS}

Another important element of Qatar's foreign policy is its direct interventions in conflicts since the beginning of the Arab uprisings in 2011. Since then, Qatar has altered its foreign policy strategy significantly. Instead of playing the neutral broker in regional conflicts and seeking good relations with everyone, Doha took now sides with the protest movements in North Africa and the Middle East. The main beneficiary is the transnational Sunni Islamist Organization of the Muslim Brothers to which Qatar has always had very close relations (HAYKEL, 2013b; ROBERTS, 2014). By shifting to a more interventionist foreign policy, Qatar became a conflicting party itself (ULRICHSEN, 2013; STEINBERG, 2012).

In Libya, Qatar strongly supported the Libyan uprising against the regime of Muammar Qaddafi in various ways: Diplomatically, Qatar secured the Arab Leagues support for NATO's military intervention; militarily, it assisted NATO's operation with its own air force and deployed hundreds of troops in Libya; and financially, it has provided the rebels with 400 million Dollars. Qatar was the first Arab state that recognized Libya's National Transitional Council (STEINBERG, 2012, p. 4). As a gesture of gratitude, the rebels have temporarily raised the Qatari flag on the presidential place right after the fall of Qaddafi's regime. Now, three years after the attacks, Libya descended into chaos; the militias of rival tribes continuously fight each other and the country is on the brink to fall apart (WEHREY; COLE, 2013; KUPERMAN, 2013).

The uprisings also reached Syria in 2011 and caused a persistent and complex civil war. Although Qatar used to have good relations with the Syrian regime, it began to support the opposition (STEINBERG, 2012, p. 5-6). Notwithstanding the Arab League's arms embargo against Syria in 2011, Qatar (together with and Saudi Arabia) became the main arms supplier of the Syrian rebels with weapons being sent to northern Syria via Turkey, as Hugh Griffiths from the Stockholm International Peace Research Institute told the New York Times (CHIVERS; SCHMITT, 2013).

Qatar has successfully pressured the Arab League to suspend Syria's membership and to acknowledge the Syrian National Council as Syria representative. After the Syrian crisis also led to a split with the former Syrian ally Hamas (the Palestinian offshoot of the Muslim Brotherhood Organization), its exiled leadership has moved from Damascus to Doha. 
Overall, Qatar's new interventionist foreign policy strategy is risky. This is even more evident, since the developments in Egypt and Syria are not as expected and hoped. Qatar's miscalculations do not support the soft power argument, but they could bring Qatar in conflict with more powerful states like its neighbour and Syria-ally Iran (STEINBERG, 2012).

\section{Alliance With the U.S.}

Finally, another salient feature of Qatar's foreign policy is its alliance with the U.S. The U.S. sees in Qatar a stable and reliable partner with influence on various groups and states in the region. Qatar on the other hand benefits from the alliance in terms of security as it is potentially threatened by Iran. Since 2003, Qatar is even home of the largest U.S. air base in the Middle East (STEINBERG, 2012, p. 2). Most recently, on July 15 2014, the US and Qatar have signed a contract that included Qatar's purchase of Apache attack helicopters, air-defence systems and other military equipment for $\$ 11$ billion. That makes this arms deal America's largest one this year (U.S. SIGNS..., 2014).

The U.S.-Qatari partnership is mutual beneficial and purely strategic. "Soft power influence", as assumed by Antwi-Boateng, can barely explain the alliance of these two unequals. Realists would call Qatar's strategy simply bandwagoning - a much more suitable concept for the given context.

\section{Conclusion}

Given the popular use of the soft power concept to describe Qatar's rising international influence, the purpose of this paper was to test thoroughly its validity. By analysing Qatar's possible soft power in terms of culture, political values and foreign policy, it must be concluded that soft power explanations in the context of Qatar are mainly unsuitable and misleading.
Apart from being a quite intangible concept, the study has shown that soft power cannot accurately describe the nature of Qatar's international influence. That is because its power does not rest on its attractiveness, neither in terms of "culture" nor in terms of "moral values". Instead, the study could reveal that it is Qatar's enormous wealth that allows it to "affect outcomes". Its achievements concerning its conflict mediation policy, its influence in international companies and organizations, its relatively huge foreign population, and even its right to stage the 2022 World Cup would not have been possible without payments, which according to Joseph Nye is a form of "hard power".

Another important factor for Qatar's significant influence is its authoritarian and monarchic political system in which policy decisions are made by a small group of people without any constraints of consensus-finding. In addition, Qatar's emirs, since 1996, pursue actively a foreign policy strategy to make their tiny state a recognized and legitimate actor in the international arena. The ultimate goal of Qatar's foreign policy agenda is security, as the vulnerable state is potentially threatened by neighbouring great powers such as Iran and Saudi Arabia. Its strategic alliance with the U.S. - realists would call it bandwagoning - helps Qatar to survive as a sovereign state. Since the beginning of the Arab uprisings, Qatar has changed its foreign policy as it makes even use of a second hard power resource: military power - most evidently exercised in Libya and Syria.

It can further be concluded that the phenomenon of Qatar can without difficulties be described and explained by mainstream IR theories. All main IR theories, including the realist tradition, recognize that power is not purely military power but also includes material and financial resources as well as diplomatic skills. Neo-Marxists certainly assert the strongest correlation between economic 
and political power. Also Robert Keohane, one of the most important proponents of liberal institutionalism, understands power as control over resources such as raw materials, markets, and sources of capital (KEOHANE, 2005: 32ff.).

This shows that soft power is not only an inaccurate but also redundant analytical tool in regard of Qatar's international influence.

\section{References}

QATAR: my sleep is my break: exploitation of migrant domestic workers in Qatar. London: Amnesty International, 2014.

THE DARK side of migration: spotlight on Qatar's construction sector ahead of the world cup. London: Amnesty International, 2013.

ANTWI-BOATENG, Osman. The rise of Qatar as a soft power and the challenges. European Scientific Journal, special edition, v. 2, p. 39-51, Dec. 2013.

RECALLING GCC ambassadors from Doha: a background and future predictions. [S.1.]: ACRPS, 2014.

ATKINSON, Carol. Does soft power matter? A comparative analysis of student exchange programs 1980-2006. Foreign Policy Analysis, v. 6, n. 1, p. 1-22, Jan. 2010.

BARAKAT, Sultan. The Qatari spring: Qatar's emerging role in peacemaking. Kuwait Programme on Development, Governance and Globalisation in the Gulf States, n. 24, July 2012. BRANNAGAN, Paul Michael; GIULIANOTTI, Richard. Qatar, global sport and the 2022 FIFA world cup. In: GRIX, Jonathan. (Ed.). Leveraging legacies from sports mega-events. Basingstoke: Palgrave Macmillahn, 2014.

BRESLIN, Shaun. The soft notion of China's 'soft power'. Chatham House, 2011.

CASTELLS, Manuel. The new public sphere: global civil society, communication networks, and global governance. The ANNALS, n.616, p. 78-93, Mar. 2008.

CHIVERS, C. J.; SCHMITT, Eric. Arms airlift to syria rebels expands, with aid from C.I.A. New York Times, Mar. 2013. Disponível em: < http://www.nytimes.com/2013/03/25/ world/middleeast/arms-airlift-to-syrian-rebels-expands-withcia-aid.html?_r=0>. Acessed: 10 jul. 2016.

DEUTSCH, Karl W. et al. Political community and the north atlantic area: international organization in the light of historical experience. Princeton: Princeton University Press, 1957.

DICKINSON, Elizabeth. How Qatar lost the middle east. Foreign Policy, 2014. Disponível: em: <http://www.foreignpolicy.com/articles/2014/03/05/how_qatar_lost_the_middle_ east>. Acessed: 10 jul. 2016.

ELDAR, Shlomi. Israel pulse: the rise and fall of $\mathrm{Al}$ Jazeera.
Al Monitor, 2013. Disponível em: < http://www.al-monitor.com/pulse/originals/2013/07/al-jazeera-political-agenda. html\#>. Accessed: 12 July 2014.

FROMHERZ, Allen J. Qatar: a modern history. Washington: Georgetown University Press, 2012.

OWEN, Gibson. We may never know how Qatar won the rights to host the 2022 World Cup. The Guardian, 2014. Disponível em: <http://www.theguardian.com/football/ blog/2014/jun/17/qatar-rights-host-world-cup-2022>. Accessed: 10 July 2014.

GRAY, Matthew. Qatar: politics and the challenges of development. Boulder: Lynne Rienner, 2013.

GENERAL SECRETARIAT FOR DEVELOPMENT PLANNING. Qatar national development strategy 2011-2016: towards Qatar national vision 2030. Doha: Gulf Publishing and Printing Company, 2011.

HALL, Todd. An unclear attraction: a critical examination of soft power as an analytical category. The Chinese Journal of International Politics, v. 3, p. 189-211, 2010.

HAMMOND, Andrew. Qatar's leadership transition: like father, like son. in: European Council on Foreign Relations, 2014.

HANSEN, Stig Jarle (Ed.). Religion, prestige and windows of opportunity? Qatari peace-making and foreign policy engagement. Noragric Working Paper, n. 48, Oct 2013.

HAYKEL, Bernard. Saudi Arabia and Qatar in a time of revolution. Center for Strategic \& International Studies. Washington, 2013a

HAYKEL, Bernard. Qatar's Foreign Policy. NOREF Policy Brief February, 2013b.

HOUNSHELL, Blake. The Qatar bubble: can this tiny, rich emirate really solve the Middle East's thorniest political conflicts? Foreign Policy, 2012. <http://www.foreignpolicy.com/ articles $/ 2012 / 04 / 23 /$ the_qatar_bubble?page $=0>$. Accessed: 13 July 2014.

WORLD report 2014: Qatar. New York: Human Rights Watch, 2014. Disponível em: <http://www.hrw.org/world-report/2014/country-chapters/qatar>. Access: 10 July 2016.

HUANG, Yanzhong; DING, Sheng. Dragon's underbelly: an analysis of China’s soft power. East Asia. v. 23, n. 4, p. 2244, 2006.

THE HOUTHIS: from Saada to Sanaa. Brussels: International Crisis Group, Middle East Report n. 154, 2014.

YEMEN: diffusing the Saada time bomb. Brussels: International Crisis Group, Middle East Report, n. 86, 2009.

LEBANON: hizbollah's weapons turn inward. Brussels: International Crisis Group, Middle East Briefing, n. 23, 2008.

KAMRAVA, Mehran. Qatar: small state, big politics. New York: Cornell University Press, 2013.

KAMRAVA, Mehran. Mediation and Qatari foreign policy. Middle East Journal, v. 65, n. 4, 2011.

KANCHANA, Radhika. Qatar's “white-collar” Indians. [S.L.]: 
e-migrinter n. 8, University of Poitiers, 2012.

KEOHANE, Robert. After Hegemony: Cooperation and Discord in the World Political Economy. Princeton: Princeton University Press, 2005.

KHATIB, Lina. Qatar's foreign policy: the limits of pragmatism. International Affair, v. 89, n. 1, 2013.

KUPERMAN, Alan J. A model humanitarian intervention? Reassessing NATO's Libya campaign. International Security, v.38, n. 1, 2013.

LENCZOWSKI, John. Full spectrum diplomacy and grand strategy: reforming the structure and culture of U.S. foreign policy. Lanham: Lexington Books, 2011.

MAKDISI, Samir; KIWAN, Fadia; MARKTANNER, Marcus. Lebanon: the constrained democracy and its national impact. In: ELBADAWI, Ibrahim; MAKDISI, Samir (Ed.). Democracy in the Arab world: explaining the deficit. New York: Routledge, 2010.

MCCLORY, Jonathan. The new persuaders: an international ranking of soft power. London: Institute for Government, 2010.

QATAR. Ministry of development, planning and statistics. Economically active population (15 years and above) by nationality, sex \& sector, http://www.qsa.gov.qa/eng/index.htm. Accessed: 9 July 2014.

SOFT power survey 2013. [S.1.]: Monocle Magazine, 2013. Available in: <http://monocle.com/film/affairs/soft-power-survey-2013/>. Accessed: 27 June 2014.

MORGENTHAU, Hans J. Politics among nations: the struggle for power and peace. $5^{\text {th }}$ ed. New York: Mc Graw Hill, 1973.

MELISSEN, Jan. The new public diplomacy: soft power in international relations, studies in diplomacy and international relations. New York: Palgrave MacMillan, 2005.

NEUBAUER, Sigurd. Qatar's changing foreign policy. Massachusetts: Carnegie, 2014. Available in: < http://carnegieendowment.org/sada/?fa=55278>. Accessed: 9 July 2014.

NIELSEN, Kristian L. EU soft power and the capability-expectations gap. Journal of Contemporary European Research, v. 9, n. 5, 2013.

NYE JÚNIOR, Joseph S. Get smart: combining hard and soft power. Foreign Affairs, v. 88, n. 4, p. 160-163, July/ Aug. 2009.

NYE JÚNIOR, Joseph S. Public diplomacy and soft power. The Annals of the American Academy of Political and Social Science, v. 616, n. 1, p. 94-109, 2008.

NYE JÚNIOR, Joseph S. Soft power: the means to success in world politics. New York: Public Affairs, 2004.

NYE JÚNIOR, Joseph S. Hard and soft power in a global information age. In: LEONARD, Mark (Ed.). Re-ordering the world: the long-term implications of 11 September. London: The Foreign Policy Centre, 2002.

NYE JÚNIOR, Joseph S. Bound to lead: the changing nature of american power. New York: Basic Books, 1991.

PESSOA, Silvia. Migrant workers in Qatar: documenting their current situation. [S.I.]: UREP Project, 2009.

RABI, Uzi. Qatar's relations with Israel: challenging Arab and gulf norms. Middle East Journal, v. 63, n. 3, Summer 2009.

U.S. SIGNS agreement for $\$ 11$ billion arms sale to Qatar. [S.1]: Reuters, 2014. Available in: < http://www.reuters.com/ article/us-usa-qatar-idUSKBN0FJ2M820140714>. Accessed: 15 July 2014.

ROBERTS, David B. Qatar, the Ikhwan, and transnational relations in the gulf. Middle east policy council, v. 21, n. 3, Fall 2014

ROSENAU, James $\mathrm{N}$. The study of global interdependence: essays on the transnationalism of world affairs. New York: Nichols Publishing Company, 1980.

RUBIN, Lawrence. The Dubai initiative: a typology of soft powers in middle east politics. Working Paper, n. 5, Dec. 2010.

STEINBERG, Guido. Qatar and the Arab spring: support for islamists and new anti-syrian policy. SWP Comments 7, Feb. 2012.

SULTAN, Nabil. Al Jazeera: reflections on the Arab spring. Journal of Arabian Studies: Arabia, the Gulf, and the Red Sea, v. 3, n. 2, 2013

TAFURO, Eleonora. Fatal attraction? Russia's soft power in its neighbourhood. FRIDE, Policy Brief, n. 181, May 2014.

TUNÇER, Erdem. Book reviews. Perceptions, v. 19, n. 2, p. 229-234, Autumn 2013.

UNESCO, Institute for Statistics: Data 2013, uploaded by Knoema: http://knoema.com/ UNESCOISD2013Jul/unesco-institute-for-statistics-data-2013?location=1001560-qatar, accessed 12 July 2014.

U.S. STATE DEPARTMENT (2011), 2010 Human Rights Report: Qatar, 2013. online: http://www.state.gov /documents/organization/160077.pdf, accessed 2 July 2014.

ULRICHSEN, Christian Coates. Qatar's mediation initiatives. NOREF Policy Brief, Feb. 2013.

ORGANIZAÇÃO DAS NAÇŌES UNIDAS PARA A EDUCAÇÃO, A CIÊNCIA E A CULTURA. Institute for statistics: data 2013, uploaded by Knoema. Available: < http://knoema. com/ UNESCOISD2013Jul/unesco-institute-for-statistics-data-2013?location=1001560-qatar>. Accessed: 12 July 2014.

U.S. STATE DEPARTMENT. Human rights report: Qatar. United States of America, 2010. Available in: <http://www.state.gov / documents/organization/160077.pdf $>$. Accessed: 2 July 2014.

WEHREY, Frederic; COLE, Peter. Building Libya's security sector. Massachusetts: Carnegie, Policy Outlook, Aug. 2013.

JONES, William J. European Union soft power: cultural diplomacy \& higher education in southeast Asia. Silpakorn University International Journal, v. 9-10, p. 41-70, 2009-2010.

WINDECKER, Gidon; SENDROWICZ, Peter. Qatar between marketing and realpolitik: a smart business model for a microstate? KAS International Reports, n. 1, 2014. 